\title{
Lighting Analysis in Traditional \& Raden Saleh Painting Room of Fine Arts \& Ceramics Museums
}

\author{
Feline Veronica Yani ${ }^{1 *}$ Bambang Deliyanto ${ }^{2}$ Augustina Ika Widyani ${ }^{3}$ \\ 1,3 Interior Design Department, Faculty of Fine Arts and Design, Universitas Tarumanagara, Jakarta 11440, Indonesia \\ ${ }^{2}$ Regional and Urban Planning Program, Faculty of Science and Technology, Universitas Terbuka, Tangerang, \\ Indonesia \\ *Corresponding author. Email: feline.615170043@stu.untar.ac.id
}

\begin{abstract}
The Fine Arts and Ceramics Museum in Jakarta has an educational and recreational function for the community. The interior design of this museum covers various aspects, especially artificial lighting related to general room lighting and special lighting for museum collections display. In supporting space users to identify every element in the room, lighting also functions as an atmosphere-forming that can affect human psychology. Artificial lighting in museum interior design is an important thing that must be considered because it can affect the quality of museum collections. Incorrectly designed artificial lighting can damage the collection surface due to the resulting heat radiation. This study aims to determine the appropriate lighting design in the Traditional and Raden Saleh Painting Room at the Museum of Fine Arts and Ceramics. The method used is the design process according to Kilmer's theory, which is simply formulated as a process of analysis and synthesis. The results of this study indicate that LED lamps can be used in museums because they do not generate heat, so they are not harmful to museum collections, also it has another advantage in energy saving.
\end{abstract}

\section{Keywords: Interior design, collections, museum, artificial lighting}

\section{INTRODUCTION}

The Fine Arts and Ceramics Museum is housed in a historic building that was founded in 1870 , located in the historic area of the old city of Jakarta. This building has undergone various changes in function since its establishment and began to be functioned as a museum in 1990. This museum not only consists of several showrooms, but also has various facilities such as a pottery studio, library, souvenir shop and a prayer room. This research is devoted to the Traditional and Raden Saleh Painting Room to get a deeper observation [1].

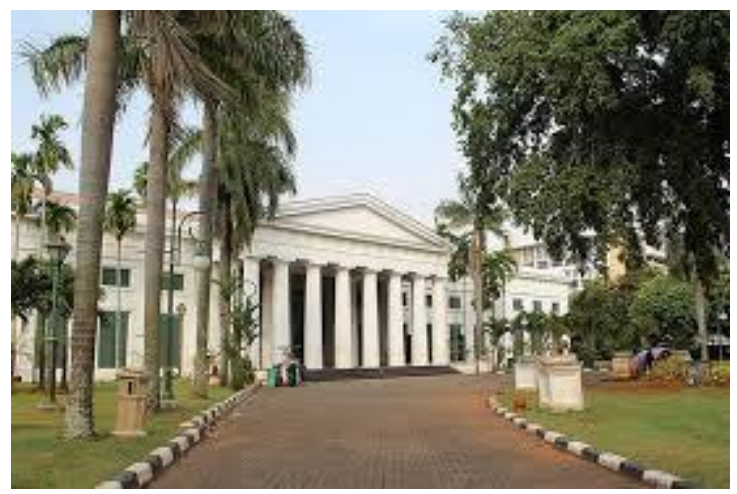

Figure 1 Building of fine arts and ceramics museum, Jakarta
Lighting has an important role in every interior design. Each lighting design concept can produce a different impression of space, so it must be adjusted to the function of the room and the purpose of interior design [2]. The interior lighting in the museum not only functions as an atmosphere for educational and recreational purposes, but also helps visitors to observe the museum's collections. According to Cayless (1991) as cited by Arief [3], the exhibition object is the centre of mama's destination in a museum and art galleries. Therefore, the lighting system in the museum must be able to provide maximum focus without changing people's perceptions of the collections.

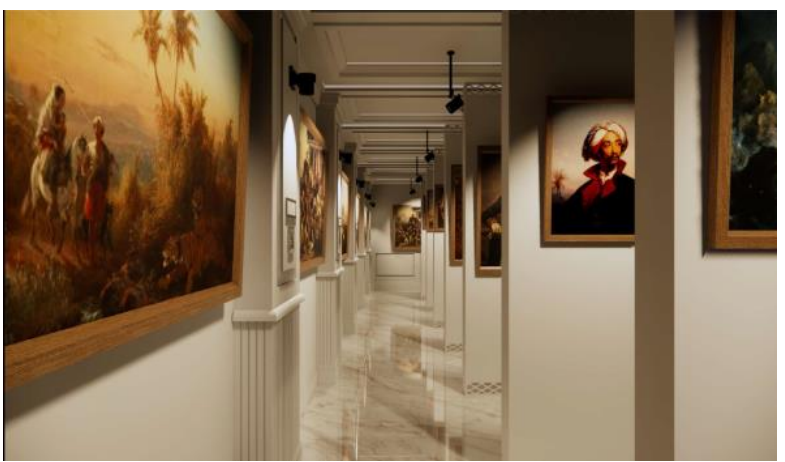

Figure 2 Lighting helps visitors in observing the collections 
The lighting in the exhibition room must be arranged for visitors to enjoy the collections calmly and comfortably. The museum must present their collections as the main strength, because at this stage there will be interactions in the museum, between the object of the exhibition and the visitors. Delivering effective communication of the objects on display for visitors who come is the most important thing to achieve the main functions of the museum, namely, to provide education and recreation to visitors.

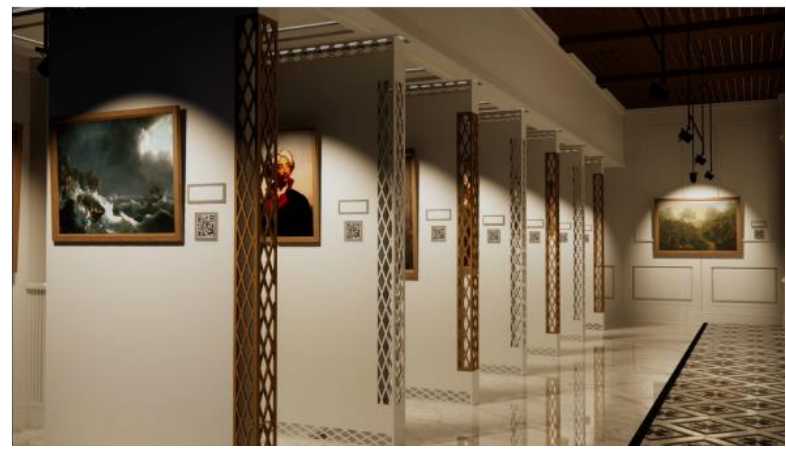

Figure 3 Lighting emphasizes the repetition and rhythm of the painting display system

Proper lighting is needed to prevent the damage of museum collections. Lighting produce light and heat with chemical reactions. This can cause collections material damage, just as the colours on clothes that are exposed to the sun continuously wear off. However, lighting cannot avoid in museum gallery because it has an important role in supporting visitors to capture the collection on display visually. There are different standards for objects with different materials, because each material has a different level of sensitivity to light exposure.

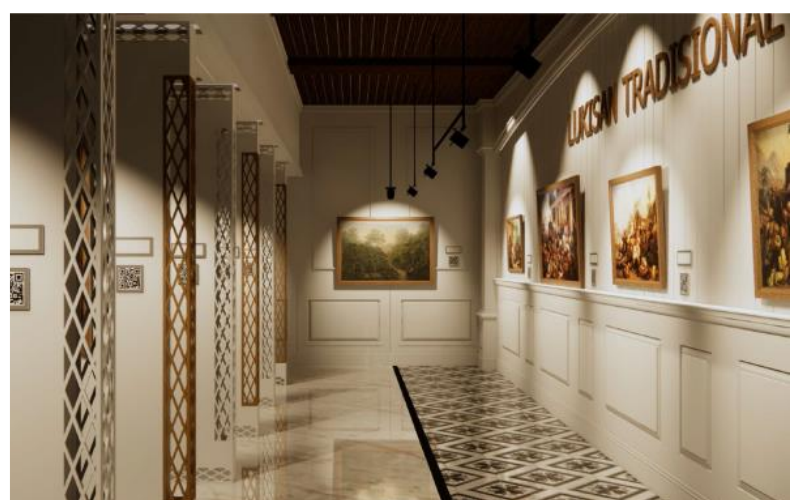

Figure 4 Museum atmosphere formed from artificial lighting

The scope of this research is the lighting standards used in the Traditional and Raden Saleh Painting Room at the Fine Arts and Ceramics Museum so that the function of conservation, education, and recreation as the main functions of the museum can be optimally achieved.

\subsection{Related Work}

Research on lighting in the interior has been conducted by Hendrastuti and Wahyudie [4] at the Borobudur Museum, showing that lighting with several technics can be a new alternative for interior redesign. Current lighting not only serves to illuminate a room but can also function as an aesthetic/ accent/ decoration element so that it can add value to the visual appearance of a room.

Research of museum lighting also published by Irwansyah [5] that conclude about the urgency of accent lighting to create a visual focus at the gallery. This research set question about the secondary lighting that insufficient to highlight the collections. This museum specially display three dimensional objects of wildlife.

Another research conducted by Ayu Wulandari [6] regarding the basics of museum interior planning, it concluded that museums in Indonesia must begin to improve themselves and begin to adopt mass communication theory combined with interpersonal communication as it has been widely applied in museums abroad. As an example of the application of the two communication theories into a museum gallery is to make the subject look impressive through the formation and atmosphere of the space and the lighting applied.

The lighting theory for museum used in this research is taken from Lighting Handbook by Rea [6]. One of the chapter of this book present the impact of lighting to improve the quality of the visual environment. Lighting quality influenced by human needs, architecture aspect, also economics and the environment. Visibility is principal to serve human needs such as (1) task performance; (2) mood and atmosphere, (3) visual comfort, (4) aesthetic judgement, (5) health, safety, and well being; and (5) social communication. Specially lighting for museums as public places and institutions, this handbook discusses about color appearance, daylight integration and control, illuminance, light distribution on task plane, reflected glare, shadows, and source/ task/ eye geometry.

\subsection{Our Contribution}

Most research of Fine Arts and Ceramics Museum Jakarta was focused on the thematic design concept to offer new experience to the visitors. As Putri [8] conducted an interior design concept with specific theme of Explore the Treasure, the design focused on the museum function to educate and to entertain society with international quality. Also a research by Lelo and Laksono [9] about Fine Arts and Ceramics Museum Jakarta has proposed an interior design theme concept, Modern Education and Ethnic Betawi, to preserve the culture and to enhance society awareness about museum collections.

Researches of museum lighting that have already done before was not for Fine Arts and Ceramics Museum Jakarta. So this paper presents a specific research of lighting for Fine Arts and Ceramics Museum. This research is important because the paintings displayed in the Traditional and 
Raden Saleh Painting Room are old paintings that are vulnerable to light.

\subsection{Paper Structure}

The rest of the paper is organized as follows. Section 2 introduces the preliminaries used in this paper, which include design problems, design objectives and researches with the same topic. Section 3 presents the design methods used to solve the design problem through design process. Section 4 discussing the application lighting design for Fine Arts and Ceramics Museum, Jakarta. Section 5 provides a conclusion on the interior design solution for museum lighting.

\section{BACKGROUND}

Museum has several function as a public space and institution. Museum serve society as an educational, cultural and recreational destination. Museums collect, preserve, analyze, and display an examples of civilization achievement. Optimal lighting must balance exhibiton needs and also protect the collection from the impact of the lighting itself, also to create an atmosphere for visitors experience [7].

Light is radiant energy that might have a negative impact to the museum collection. When the collections are exposed continually to light, it causes permanent damage to many museum objects. The surface expands relaive to the collections, and moisture is driven from the collection surface. It might be cracked, lifted of surface layers, and loss of color.

\section{METHODS}

The method used in the process of solving design problems at the Interior of the Fine Arts and Ceramics Museum is using the Kilmer design process [2], in general the process is divided into data collection and data analysis methods. Literacy data collected from journals, books, and other library sources regarding the interior design of the museum, especially physical and non-physical data regarding the Museum of Fine Arts and Ceramics. The data were analysed using the theory of interior design and lighting in interior design, which can be accounted for as well as observations of the design results that have been designed which are then analysed qualitatively to produce the final research results and conclusions.

\section{FINDINGS AND DISCUSSIONS}

Lighting is an important aspect in interior design, including for the gallery in the museum. However, the damage that light can be resulted is inevitable. The energy that comes from light can accelerate the damage, and this of course will have a negative impact on museum collections that are valuable. The lighting should provide satisfactory viewing conditions with minimum irradiance of the collections.
Techniques such as elimination of glare and control of surrounding brightness can serve to reduce the need for light on the artifacts.

Visible light contributes to booth vision and damage. Infrared (IR) and ultraviolet (UV) energy, which are not visible, contribute only to damage. Unless all artifacts in a display area are totally insensitive to exposure, UV and IR should be controlled with filters.

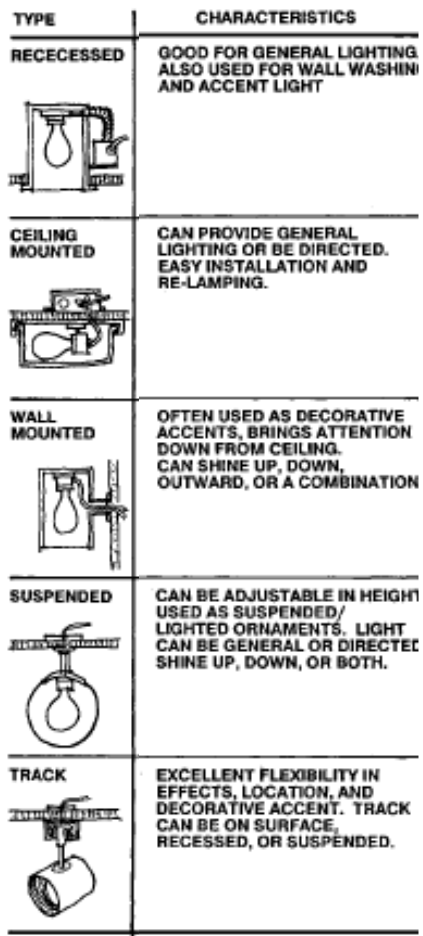

Figure 5 Types of lighting hanging on the ceiling

In the exhibition space, the most dominant light level lies on the surface of the collections themselves. This refers to the spotlights that are often found in museum gallery. The light from the spotlight will shine directly on the surface of the collections.

There are four typical lighting situations found in museums: (1) Flat display on Vertical Surface; (2) Exhibit Cases; (3) Three-Dimensional Objects; and (4) Realistic Environment. Objects displayed in Traditional and Raden Saleh Painting Room are Paintings hung on the wall. In this case, lighting become difficult when acrylic or glass is used to protect the collections.

There are two methods to spot the painting collections with lighting: (1) Wall wash; (2) Spotlights. Wall wash is best to spot uniform over a large vertical surface. Spotlights would be best for small and medium size pictures mounted on a wall. 


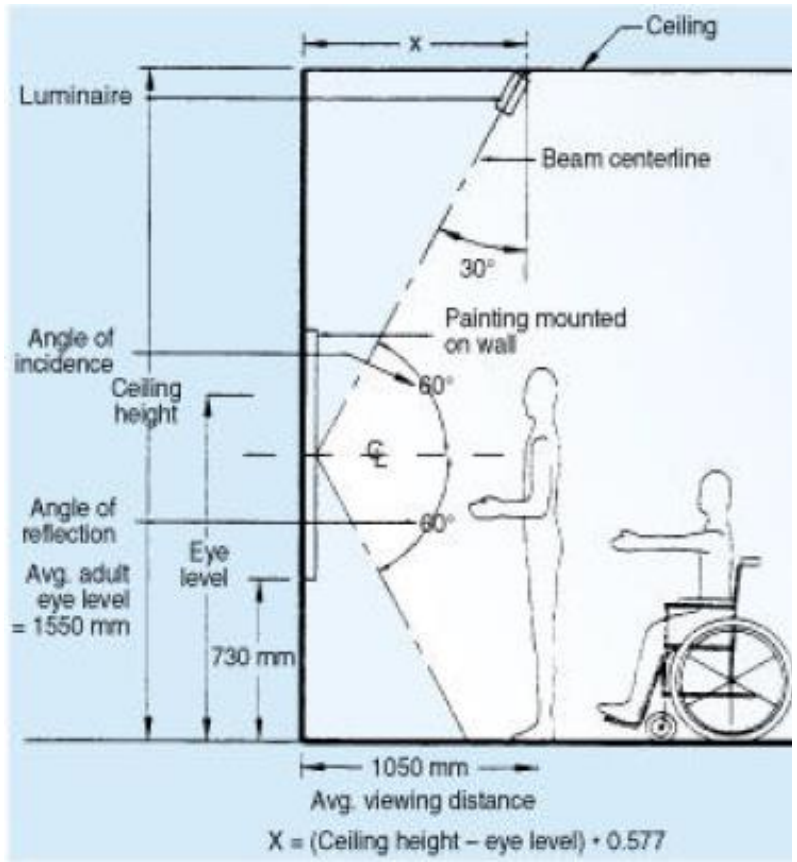

Figure 6 Mounted Lamp Position Guide for Painting

Spotlights are synonymous with halogen lamps because halogen lamps have a high beam power, making them very effective in giving maximum focus to the museum collections. Halogen lamps have a very high colour rendering index, which is close to 100 , the highest scale of the Colour Rendering Index (CRI). This allows halogen lamps to display the colours of collections in a very high degree of accuracy. However, the use of halogen lamps has a negative impact on the durability of collectibles. Halogen lamps have very high thermal power. Heat can produce chemical reactions that can cause material deterioration and cause discoloration of collections if exposed continuously for a long time.

In designing the Traditional \& Raden Saleh Painting Room, the types of lamps proposed are LED lights. Although the beam power and rendering rate are not as good as halogen lamps, LED lights do not generate heat which is very good for preserving durability and supporting the conservation function of the Museum. Currently, the highest colour rendering index of LED lamps reaches 95, which makes LED lamps able to display the colour accuracy of the collections quite well.

The collections on display at the Traditional and Raden Saleh Painting Room are works of painting made of paper and cloth and have various colours. Based on the provisions of the illumination value issued by the Illumination Engineers Society of North America (Lighting Handbook for General Use), objects made of paper have the highest sensitivity to light.
Table 1 Client-server experimental results

\begin{tabular}{|c|c|c|}
\hline Room & Material & $\begin{array}{c}\text { Light Levels } \\
\text { (FC/ Foot } \\
\text { Candle) }\end{array}$ \\
\hline $\begin{array}{c}\text { Gallery } \\
\text { (very sensitive) }\end{array}$ & $\begin{array}{l}\text { Paper, print, } \\
\text { cloth, leather, } \\
\text { colored objects }\end{array}$ & $5-10$ \\
\hline $\begin{array}{c}\text { Gallery } \\
\text { (sensitive) }\end{array}$ & $\begin{array}{l}\text { Oil painting, and } \\
\text { tempera, wood }\end{array}$ & $15-20$ \\
\hline $\begin{array}{c}\text { Gallery } \\
\text { (less sensitive) }\end{array}$ & $\begin{array}{l}\text { Glass, stone, } \\
\text { ceramic, metal }\end{array}$ & $30-50$ \\
\hline $\begin{array}{l}\text { Collections } \\
\text { Storage }\end{array}$ & & 5 \\
\hline $\begin{array}{c}\text { Collections } \\
\text { Treatment }\end{array}$ & & $20-50$ \\
\hline
\end{tabular}

The LED lamps used in the Traditional and Raden Saleh Painting Room have an energy level of 5 watts for each spotlight. LED lamps with 5 watts of energy can generally produce 570 lumens of light. Lumen is the intensity of light produced from a light source, while lux is the intensity of light on the surface of an illuminated object that measures the light flux per unit area, in this case, per square meter. Foot-candle or FC has the same meaning as lux, except that foot-candle is calculated in per square foot or per square foot. To determine the foot-candle light level produced by a 5 watts LED lamp with a light intensity of 570 lumens, the calculation to determine the level of lux must be done first. How to calculate lumens is quite easy, just by dividing the lumen produced by the light source by the area exposed to light.

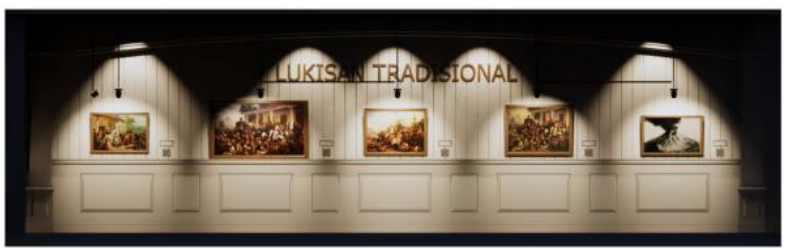

Figure 7 Fields for collections exposed to light

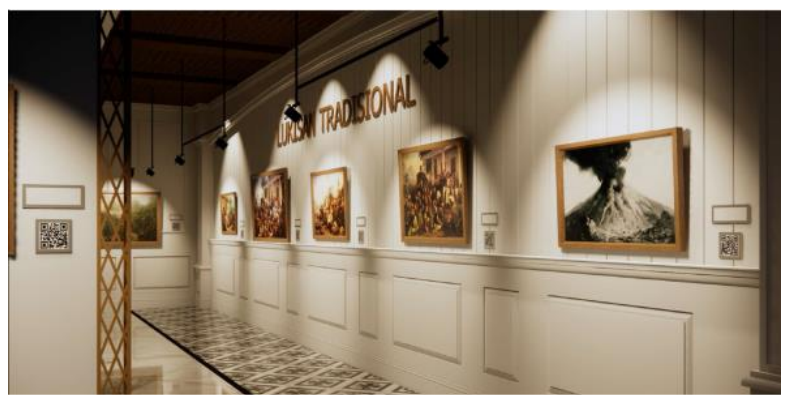

Figure 8 Five fields of painting display on a wall

As it has been described by Yani [10], there are five areas separated by columns, each area is for a collection of paintings with one spotlight that highlights the painting directly. It can be seen from the picture above, one area has an area of $5.5 \mathrm{~m} 2$. With the existing formula, it can be calculated that the level of lux produced by a 5 watt LED 
lamp with a light intensity of 570 lumens in a $5.5 \mathrm{~m} 2$ area is 103.6 lux.

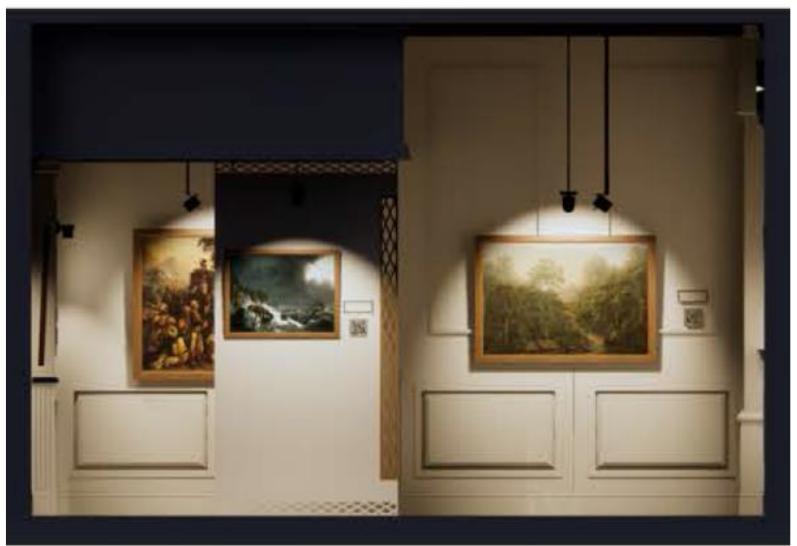

Figure 9 Artificial lighting in the traditional and Raden Saleh painting room

Furthermore to change the lux unit into a foot-candle unit to be compared with the standard light level in table 1.1 lux is equivalent to 0.093 foot-candle, so that $103.6 \mathrm{lux}$ is equivalent to 9.6 foot-candle (FC). Based on data from table 1 , the light level for the showroom with collectibles made of paper, print, cloth, leather, colors ranges from $5 \mathrm{FC}$ and may not pass $10 \mathrm{FC}$. With the results of calculations that have been done, the lighting applied to the Traditional and Raden Saleh Painting Room is in accordance with existing standards so that the quality of the collections is maintained.

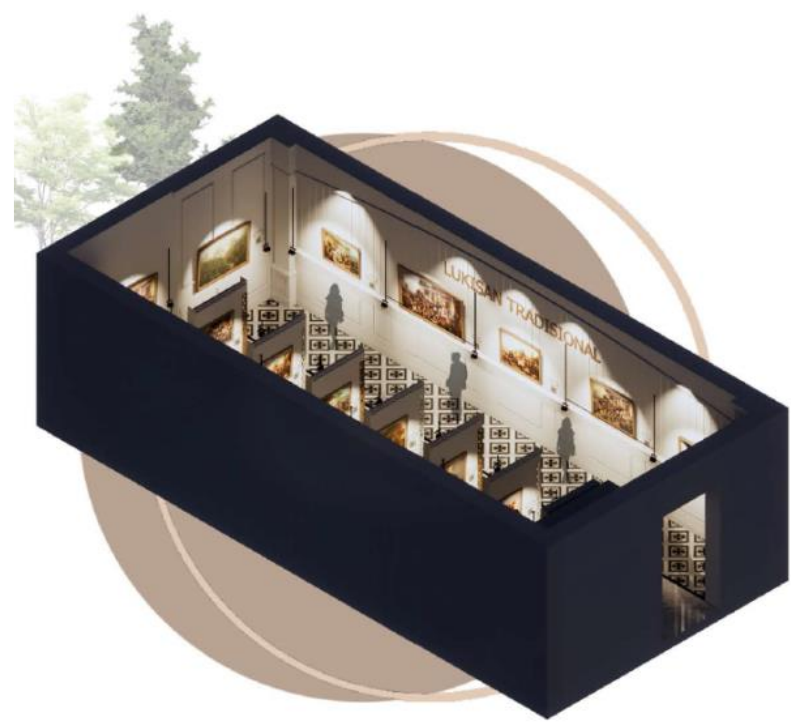

Figure 10 Axonometry of traditional and Raden Saleh painting room

The type of lighting applied to the Traditional Painting Room and Raden Saleh is downllight. The spotlight is installed hanging from the ceiling with a tracklight system which will then highlight the collection objects. This type of lighting will produce an even distribution of light on the surface of the object that is highlighted with a large light distribution angle. Evenly distributed light will make objects appear as they are, which is very important in a gallery. There is no meaningful lighting technics for shadow effects or other effects, because it can only work on 3dimensional objects, while in the Traditional and Raden Saleh Painting Room the objects on display are 2dimensional objects.

The color temperature of the LED lights used in the Traditional Painting Room and Raden Saleh is $3000 \mathrm{~K}$ or soft white. The use of soft white LED lights aims to provide a peaceful and calming psychological effect to visitors. In addition, the use of soft white color temperature in the room aims to build a dramatic atmosphere and atmosphere.

Lighting controls for museum must also limit or remove UV radiation, shield sensitive objects from sunlight, create visual drama within display, and limit the time artifacts are exposed to all visible light.

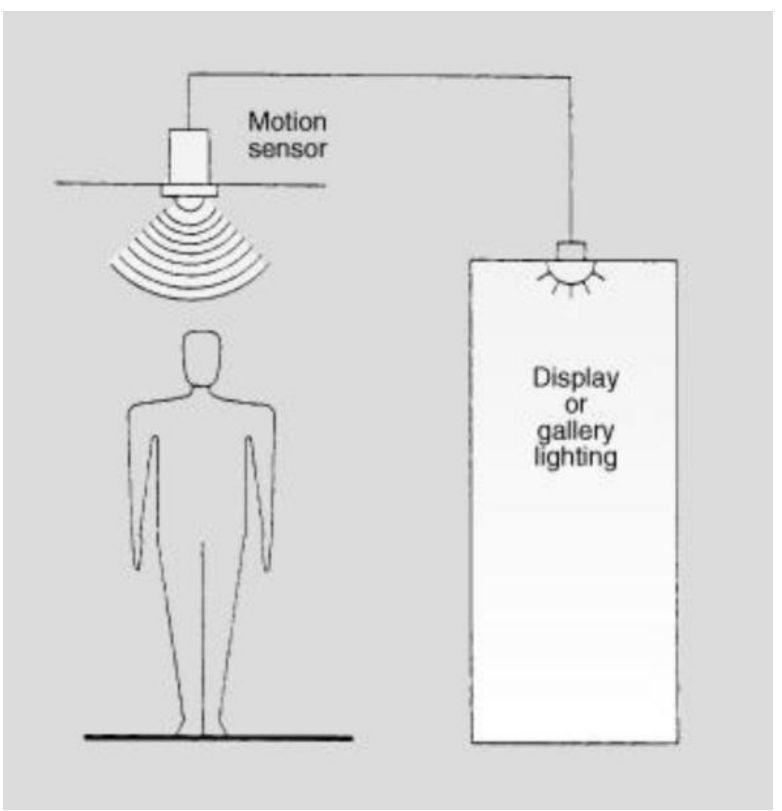

Figure 11 Motion sensor systems detect the approach of a person and then illuminate the displays. The lights remain low or off until actually needed.

\section{CONCLUSIONS}

Lighting is an important aspect in interior design, including the gallery in the museum. The lighting in the museum gallery must be in accordance with existing standards so as not to damage collections. The use of LED lamps aims to maintain the durability of the collection because LED lamps do not generate heat. LED light also has a high colour rendering index of 95 .

The collections on display at the Traditional and Raden Saleh Painting Room are works of painting made of paper and cloth and have various colours. Based on the provisions of the illumination value issued by the Illumination 
Engineers Society of North America (Lighting Handbook for General Use), the light levels for showrooms with collectibles made of paper, print, fabric, leather, colours range from $5 \mathrm{FC}$ and may not be past $10 \mathrm{FC}$.

Results of the calculations showed that the level of light per area of collections in the Traditional and Raden Saleh Painting Room are 9.6 foot-candles (FC), so it can be concluded that the lighting is appropriate with standardization. The type of lighting applied to the Traditional and Raden Saleh Painting Room is downlight which produces an even distribution of light on the surface of the object with a large light distribution angle. Evenly distributed light will make objects appear as they are. There is no meaningful lighting technics, because it can only work on 3-dimensional objects, whereas paintings are 2dimensional objects. As for the use of LED lights with a colour temperature of $3000 \mathrm{k}$ (soft white) to provide a calming effect and aim to build a dramatic atmosphere and atmosphere.

\section{REFERENCES}

[1] "museumindonesia.com," Museum Indonesia, [Online]. Available: http://www.museumindonesia.com/ museum/37/1/Museum_Seni_Rupa_dan_Keramik_Jaka rta. [Accessed 20 January 2021].

[2] R. Kilmer and O. W. Kilmer, Designing Interior, New Jersey: Wiley, 2014.

[3] G. H. Arief, "Analisa Pencahayaan Buatan dan SIrkulasi pada Area Display Kendaraan Museum Otomotif Sentul," in Art \& Design Vol.3 No. 3 Telkom University, Bandung, 2016.

[4] S. Y. Hendrastuti and P. Wahyudie, "Desain Interior Museum Borobudur dengan Pencahayaan sebagai Aksen dan Penunjang Visual," Jurnal Sains \& Seni ITS, vol. 5, no. 2, 2016.

[5] Irwansyah, "Analisis Tata Pencahayaan Interior Wildlife Museum \& Gallery Rahmat Internasional di Medan," Jurnal Proporsi, vol. 4, no. 1, pp. 50-62, 2018.

[6] A. A. A. Wulandari, "Dasar-Dasar Perencanaan Interior Museum," Humaniora, vol. 5, no. 1, 2014.

[7] M. S. Rea, The IESNA Lighting Handbook: Reference \& Application, New York: PUblications Department of IESNA, 2000.

[8] F. C. S. A. Putri, Suastiwi and S. B. Astana, "Perancangan Interior Museum Seni Rupa dan Keramik di Kawasan Kota Tua Jakarta," Fakultas Seni Rupa, ISI Yogyakarta, Yogyakarta, 2017.
[9] Lelo and M. A. Laksono, "Perancangan DesainInterior Museum Seini Rupa dan Keramik Jakarta," Narada, Jurnal Desain \& Seni, vol. 5, no. 2, pp. 9-21, 2018.

[10] F. V. Yani, B. Deliyanto and A. I. Widyani, "Perancangan Interior Museum Seni Rupa dan Keramik (MSRK) Jakarta," Universitas Tarumanagara, Jakarta, 2021. 